\title{
Carpological features of Lonicera L. (Caprifoliaceae Juss.) of the flora of Ukraine
}

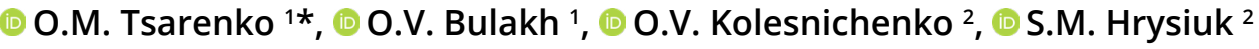 \\ 1 M.G. Kholodny Institute of Botany, National Academy of Sciences of Ukraine, Tereschenkivska str. 2, 01004 Kyiv, Ukraine; \\ * tsarenko_olga@ukr.net \\ ${ }^{2}$ National University of Life and Environmental Sciences of Ukraine, Heroiv oborony str. 15, 03041 Kyiv, Ukraine
}

Received: 03.03 .2020 | Accepted: 25.04.2020 | Published: 30.06 .2020

\begin{abstract}
The objective of this study was to carry out macro- and micromorphological studies of fruits and seeds of representatives of the genus Lonicera of the flora of Ukraine (both natural and introduced), to clarify their features, to provide additional characteristics and to evaluate the possibility of using carpological features for the diagnosis of taxa of the genus.

Material and methods. Materials of the National Herbarium of the M.G. Kholodny Institute of Botany of the National Academy of Sciences of Ukraine (KW) and Herbarium of the M.M. Gryshko National Botanical Garden of the National Academy of Sciences of Ukraine (KWHA) were used, as well as samples from living plants from the collections of the M.M. Gryshko National Botanical Garden and O.V. Fomin Botanical Garden. The citations are given by the original text of the labels. The fruits and seeds of seven species of the genus (four are introduced, and the other are species of natural flora), which are listed in "Vascular plants of Ukraine. A nomenclatural checklist", have been studied. Morphological features of fruits and seeds were studied under the light microscope (LM, MBS-9) and scanning electron microscope (SEM, JSM-6060 LA). Samples were sprayed with a layer of gold according to the standard method. The study was conducted at magnification from $\times 30$ to $\times 3000$. Descriptions of fruits and seeds were performed using terminology, summarized in specialized papers. Fruit and seed sizes were measured using Axio Vision Rel. 4.8.
\end{abstract}

Results. The fruits of Lonicera species are free or adnate at the base, surrounded by, for the most part, free bracteoles. A pseudocarp of $L$. caerulea is formed of the bracteoles of paired flowers concrescent in a tubular cupule, which completely and tightly wraps free paired fruits. The L. nigra has an uneven concrescent of the bracteoles that freely surround the paired fruits, which have concrescent only at the base. The fruits of the species Lonicera are black and dark blue, or red and yellow. The fruits of subgenus Periclymenum (L. caprifolium, L. etrusca, L. periclymenum) are free and spherical. The subgenus Chamaecerasus species' fruits are mainly spherical, but in some species the fruits are also hemispherical, elliptical and elongated (L. caerulea, L. tatarica). Fruits in this subgenus are free (L. caerulea, L. tatarica) or coalescent at the base (L. nigra, L. xylosteum). All the studied species are characterized by glabrous fruits, except fruits of L. xylosteum that are pubescent with glandular and simple hairs. The seeds are elliptical, ovoid, nearly spherical, flat, concave on one side and convex on the other side, with a recess on the periphery and a crest in the center, at the base they are mainly narrow-rounded. All species of the section Eucaprifolium and one species of the section Coeloxylosteum have truncated seeds. The surface of the seeds is almost similar and pitted; in L. xylosteum it is shallow-pitted; in L. nigra it is tubercular-pitted. In some species, the seed surface is pitted, and also flat cells are present.

Conclusions. Based on the results of a critical review of literature materials and analysis of own data, the detailed characteristics of fruits and seeds of the representatives of the genus Lonicera within the flora of Ukraine have been compiled. These characteristics are useful for more accurate identification of fruiting Lonicera plants. The species of the subgenus Periclymenum have exclusively free fruits, while the fruits in the subgenus Chamaecerasus are free or coalescent at the base. The features of color and shape of the fruits 
and seeds, the peculiarities of pubescence of the fruits, are suggested to be used to distinguish $L$. caerulea, L. caprifolium, L. etrusca, L. nigra, L. periclymenum, L. tatarica, and L. xylosteum. Analysis of the microstructure of the surface of the seeds revealed that there no features that can be used as diagnostic at the level of subsections, sections, and subgenera. However, seeds microstructure showed some differences at the species level.

Keywords: Lonicera, fruit, seed, macromorphology, micromorphology, surface microstructure of seed, flora of Ukraine

\section{Introduction}

The genus Lonicera is represented in the world flora by almost 200 species (Theis et al., 2008; Takhtajan, 2009). The species are distributed in all areas of the Northern Hemisphere (in temperate and subtropical regions of Europe, North and Central America, North Africa, and Asia). South-East Asia is considered to be the primary center of origin for this genus. Some representatives of this genus are decorative plants with beautiful flowers and fruits and were introduced into the culture (Browicz, 1976; Poyarkova, 1958; Zaytsev, 1962).

Mosyakin \& Fedorochuk (1999) have listed seven Lonicera species for the flora of Ukraine - four are species of natural flora (L. caerulea L., L. etrusca Santi, L. nigra L., L. xylosteum L.), and three species (L. caprifolium L., L. periclymenum L., L. tatarica L.) are introduced from other countries and are widely used in botanical gardens and parks of Ukraine (Barbarych, 1961; Zaytsev, 1962; Glukhov et al., 2002; Lavrinenko, 2016).

According to the APG IV (APG, 2016) and the results of recent phylogenetic studies of Dipsacales Juss. ex Bercht. et J. Presl, the genus Lonicera belongs to the tribe Caprifolieae of the family Caprifoliaceae Juss. (Theis et al., 2008; Takhtajan, 2009; Reveal, 2012). Also, the features of fruits and seeds of Lonicera are well discussed in the literature and listed among the morphological features confirming recent molecular-phylogenetic data on Dipsacales (Bell et al., 2001, 2005; Donoghue, 2003; Jacobs et al., 2008; Theis et al., 2008; Göktürk \& Sümbül, 2014).

Carpological characteristics are essential for the identification of these plants in the fruiting stage. The information on the morphological features of seeds is also important for specialists in botanical gardens and arboretums, who directly work with seeds during the seed exchange programs.
It is also important to note, most of the authors of the monographic elaboration of the genus Lonicera in the regional Floras and Identification Keys usually used features of the perianth, a number of flowers on the shoot apex, shoot pubescence, and shape of leaves to delimit taxa. They only briefly focused on the characteristics of fruits (color, size) and seeds as supporting features (Rehder, 1909; Poyarkova, 1958; Barbarych, 1961; Zaytsev, 1962). Despite this, we believe, that carpological features (including micromorphological peculiarities) play an essential role in diagnostics and identification of species in the genus Lonicera, in particular those represented in the flora of Ukraine, during the fruiting stage.

The fruits of Lonicera are inferior syncarpous succulent multi-seeded berries with various colors - yellow, dark-red, blue, and black. They are arranged in pairs, free or coalescent at the base, often one of the paired berries may be underdeveloped. The ovary contains 2- or 3-4 locules with a double-rowed location of numerous anatropous ovules with one massive integument (Plysko, 2000). The species of Lonicera are characterized by different levels of coalescence of adjacent fruits. Free fruits were found in L. syringantha Maxim.; partial fusion was found in L. canadensis Bartram ex Marshall and L. tatarica, and the highest coalescence of adjacent fruits is typical for L. caerulea (Artiushenko \& Fedorov, 1986; Plysko, 2000).

Malinkina (2001) found that L. tatarica and L. xylosteum have a pair of inferior syncarpous 3-locular ovaries, which unified on a single pedicel with two free bracts. At the base of each ovary, there are two small round bracteoles, which are partially fused with the ovary. Some species have coalescent bracteoles, which form a cupule enclosing the ovaries (Poyarkova, 1958).

Zaitseva (1998, 1999, 2006) studied the organogenesis of the Lonicera fruit in detail. 
At the beginning of fruit development, 2-3 layers of cells separate from the outer epidermis and together form the exocarp. Between these layers there is a layer of parenchyma cells - mesocarp. The pericarp of the fruit of Lonicera is formed from similar parenchymal cells.

The cells of the exocarp are polygonal in most species in cross-section. The cells of mesocarp are round and thin-walled, containing chromoplasts and drops of oil. The inner part of the mesocarp is rich in calcium oxalate. Endocarp is usually reduced to a single unsclerified layer of cells (Artiushenko \& Fedorov, 1986; Plysko, 2000; Jacobs et al., 2009).

The seeds are early separated from the pericarp. Developed seeds have a small (up to $1 / 6-1 / 4$ length of seed), straight, well-differentiated embryo. The embryo is surrounded by a well-differentiated endosperm and a multilayered spermoderm with lignified exotesta cells (Malinkina, 2001; Jacobs et al., 2009; Lavrinenko, 2012). The microstructure of the seed surface is specified by the features of the walls of exotesta cells. Anticlinal and periclinal walls of exotesta are thickened, lignified, and have pores. The hilum is small, submerged, located at the base of the seed (Jacobs et al., 2009; Lavrinenko, 2012).

Analyzing research articles (Rehder, 1909; Barbarych, 1961; Zaytsev, 1962; Artiushenko \& Fedorov, 1986; Zaitseva, 1998, 1999, 2006; Glukhov et al., 2002; Jacobs et al., 2009; Lavrinenko, 2012, 2016), we found that a number of questions regarding carpological characteristics of the genus Lonicera remained outside the attention of researchers (i.e., features of the fruits pubescence, surface microstructure of the seeds, etc.). This fact motivated us to investigate macro- and micromorphology of the fruits and seeds of Lonicera of the flora of Ukraine. These studies were aimed to provide additional characteristics of the fruits and seeds and to evaluate the possibility of application of carpological features for the identification of Lonicera specimens.

\section{Material and methods}

Specimens preserved in the National herbarium of M.G. Kholodny Institute of Botany of the National Academy of Sciences of Ukraine (KW) and the Herbarium of M.M. Gryshko National Botanical Garden of the National Academy of Sciences of Ukraine (KWHA), and also selected specimens from living collections of M.M. Gryshko National Botanical Garden and O.V. Fomin Botanical Garden were used during the research. The fruits and seeds of all seven species listed in the "Vascular plants of Ukraine. A nomenclatural checklist" (Mosyakin \& Fedoronchuk, 1999) were investigated. Morphological features of the seeds and fruits were studied using a light microscope (LM, MBS-9) and scanning electron microscope (SEM, JSM-6060 LA). The study was conducted at magnification from $\times 30$ to $\times 3000$. Descriptions of fruits and seeds were performed using terminology, summarized in a number of relevant specialized papers (Artiushenko \& Fedorov, 1986; Plysko, 2000; Ziman et al., 2004, 2011). Fruit and seed sizes were measured using Axio Vision Rel. 4.8.

\section{Results}

Investigated species belong to two subgenera: Chamaecerasus (L.) Rehder (sections Isika (Adanson) Rehder and Coeloxylosteum Rehder) and Periclymenum (L.) Rehder (section Eucaprifolium (Spach) Pojarkova). Based on published materials and obtained results, their characteristics have been compiled. The species are listed below according to the system of the genus Lonicera represented in the "Flora of the USSR" (Poyarkova, 1958).

\section{Genus Lonicera L.}

\section{Subgenus Chamaecerasus (L.) Rehder Section Isika (Adanson) Rehder Subsection Caeruleae (Rehder) Nakai} Lonicera caerulea L. (Fig. 1; Tables 1 \& 2)

Two fruits are free. A pseudocarp is formed by bracteoles of two paired flowers, which are connate in a common tubular cupule. Cupule completely and tightly wraps free paired fruits. The fruits are dark blue, with bluish cover, fleshy, spherical, hemispherical or elliptical, $8-11 \mathrm{~mm}$ in diameter, containing up to $10-20$ $(-30)$ seeds.

The seeds are light- or dark-brown, broadly elliptical or rounded, $1.5-2.3 \mathrm{~mm}$ long and 1.4-2.1 mm wide, flat, slightly concave on one 

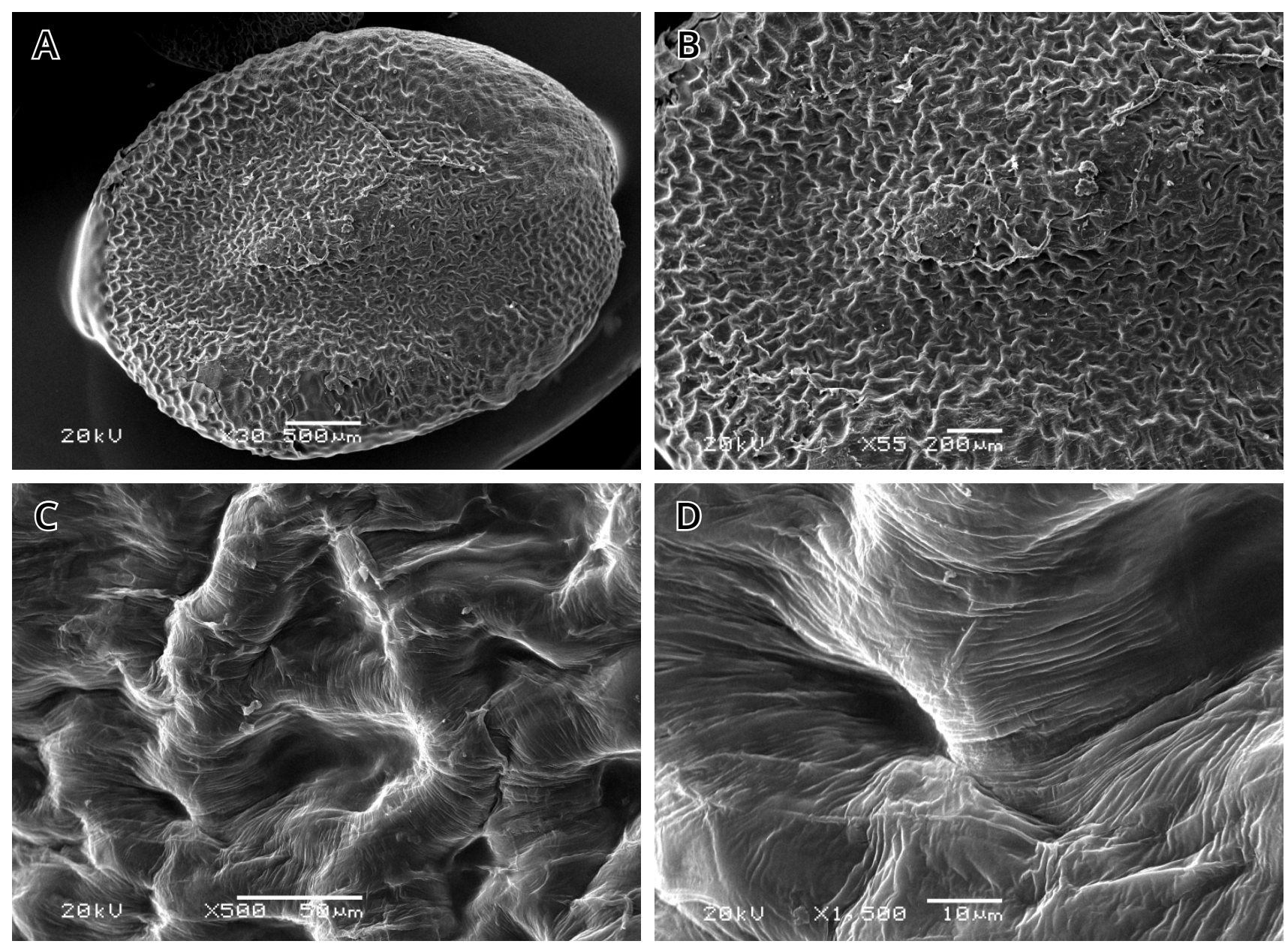

Figure 1. The seed of Lonicera caerulea: A - general view; B-D - surface at different magnification.

side, convex on the other, with a cavity on the periphery and a crest in the center, at the base narrow-rounded, with a small notch. The hilum is small, submerged, located at the base of the seed.

The surface of the seed is mostly pitted. Exotesta cells are polygonal, with concave periclinal and distinctly visible anticlinal walls. The outer periclinal walls have ribs, which become visible at the magnification over $\times 500$. Ribs were without clear orientation.

Samples examined: 1. Transcarpathian region, Rakhiv district, around village Kvasy, the north-western slope of Mt. Petros, among stones covered with sphagnum moss, occurs in the form of small thickets, 24.VIII.1957. Leg., det. [SM?] Kazakevich (KW); 2. Living plants from the collection of the M.M. Gryshko National Botanical Garden NAS of Ukraine, 26.IX.2017. Leg., det. O.M. Tsarenko; 3. Living plants from the collection of the O.V. Fomin Botanical Garden, 20.VII.2017. Leg., det. N.M. Belemets, O.M. Tsarenko; 4. Carpathians, Chornohora, Mt. Petros, $1850 \mathrm{~m}$, on the rocky placers of the south-western slope of the mountain between the krummholz (Pinus mugo), 9.VIII.1954. Leg., det. K. Malinovski (KWHA).

\section{Subsection Rhodanthae (Maximowicz) Rehder Lonicera nigra L. (Fig. 2; Tables 1 \& 2)}

The infructescence consists of two fruits connate at the base. Four bracteoles are irregularly and incompletely connate into a goblet-shaped cupule, which freely wraps the fruit at its base. The fruits are black, with bluish cover, fleshy, spherical, 6-10 $\mathrm{mm}$ in diameter, connate in pairs only at the base.

The seeds are light- or dark-brown, elliptical, 2.2-2.5 $\mathrm{mm}$ long and 1.8-2.4 mm wide, flat, on one side slightly concave, on the other side convex, with a cavity on the periphery and a crest in the center, at the base narrowly rounded, with a small notch. The hilum is small, submerged, located at the base of the seed.

The surface of the seed is tuberculatepitted. The cells of the exotesta are polygonal, with concave or convex periclinal and distinctly visible anticlinal walls. The outer periclinal walls are ribbed or wrinkled (seen at magnification over $\times 500$ ). 

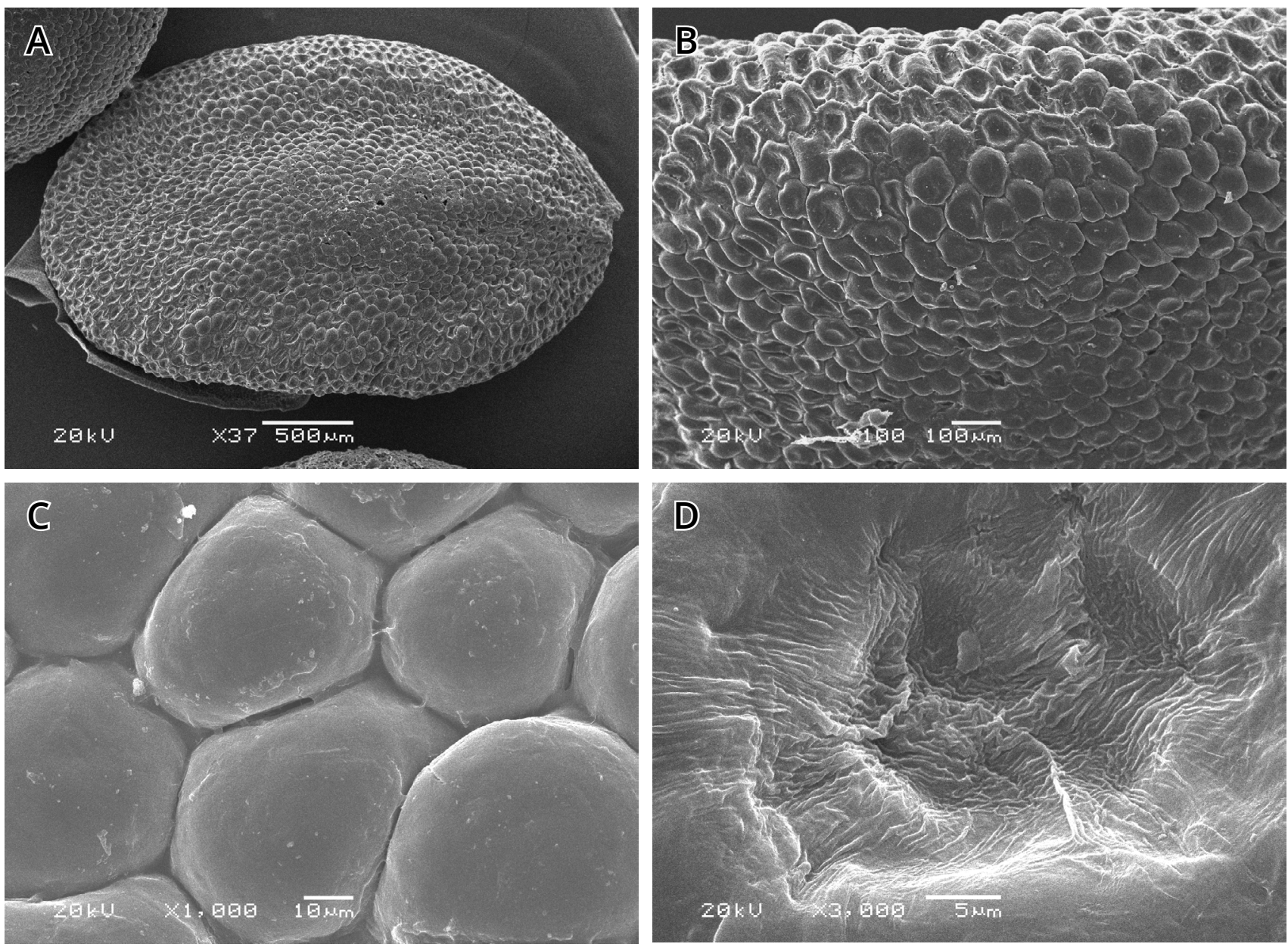

Figure 2. The seed of Lonicera nigra: A - general view; B-D - surface at different magnification.

Samples examined: 1. Transcarpathian region, Rakhiv district, climb to Hoverla, slopes to r. Hoverla at an altitude of 700 m. 27.VII.1947. Leg., det. M. Klokov (KW); 2. Chernivtsi region, Putilsky district, village Selyatin, spruce forest, Urochysche Ropachevske, on the edge of the forest. 28.VI.1947. Leg., det. N. Kosets (KW); 3. Transcarpathian region, Rakhiv district, village Bogdan, Urochysche Turkul, spruce forest, 7.VI.1953. Leg., det. Komendar (KWHA).

\section{Section Coeloxylosteum Rehder}

Subsection Tataricae Rehder emend. Nedoluzhko Lonicera tatarica L. (Fig. 3; Tables 1 \& 2)

Two free fruits, bracteoles are also free and cover the fruits to the middle. The fruits are red or yellow, fleshy, spherical, sometimes elliptical, 6-8 $\mathrm{mm}$ in diameter.

The seeds are light- or dark-brown, elliptical, $3.0-3.5 \mathrm{~mm}$ long and 1.5-2.7 mm wide, somewhat flat, slightly concave on one side, convex on the other, with a cavity on the periphery and a crest in the center, at the base narrowly rounded, somewhat truncated. The hilum is small, submerged, located at the base of the seed.
The surface of the seed is pitted. The cells of the exotesta are polygonal, with concave periclinal and distinctly visible anticlinal walls. The outer periclinal walls with ribs, which are visible at magnification over $\times 500$. Ribs do not have a strict orientation.

Samples examined: 1. Odessa region, Hadzhibey, a swamp near the village Maryanovka, 3.VII.2003. Leg., det. E.Y. Bondarenko, 124485 (KW); 2. Zhytomyr region, Korostynskyi district, around village Ushtun, forest park, quarter No. 8, 4.VI.1951, Leg., det. Barbarich (KW); 3. Kharkiv city, Zoological Garden, cultural, 30.V.1921, Leg., det. Kozlov (KW); 4. Sumy region, Middle-Stara Buta district, village Stara Buta, Desniansko-Starobutsky NNP, outskirts of pine forest, 9.VI.1997, 069875. Leg., det. Panchenko (KW).

\section{Subsection Ochranthae Zabel emend. Rehder Lonicera xylosteum L. (Fig. 4; Tables 1 \& 2)}

The infructescence consists of two fruits, which are connate only at the base. Bracteoles are free. The fruits are dark-red, yellow, fleshy, spherical, 6-9 $\mathrm{mm}$ in diameter. The surface of the fruits is sparsely pubescent with two- 

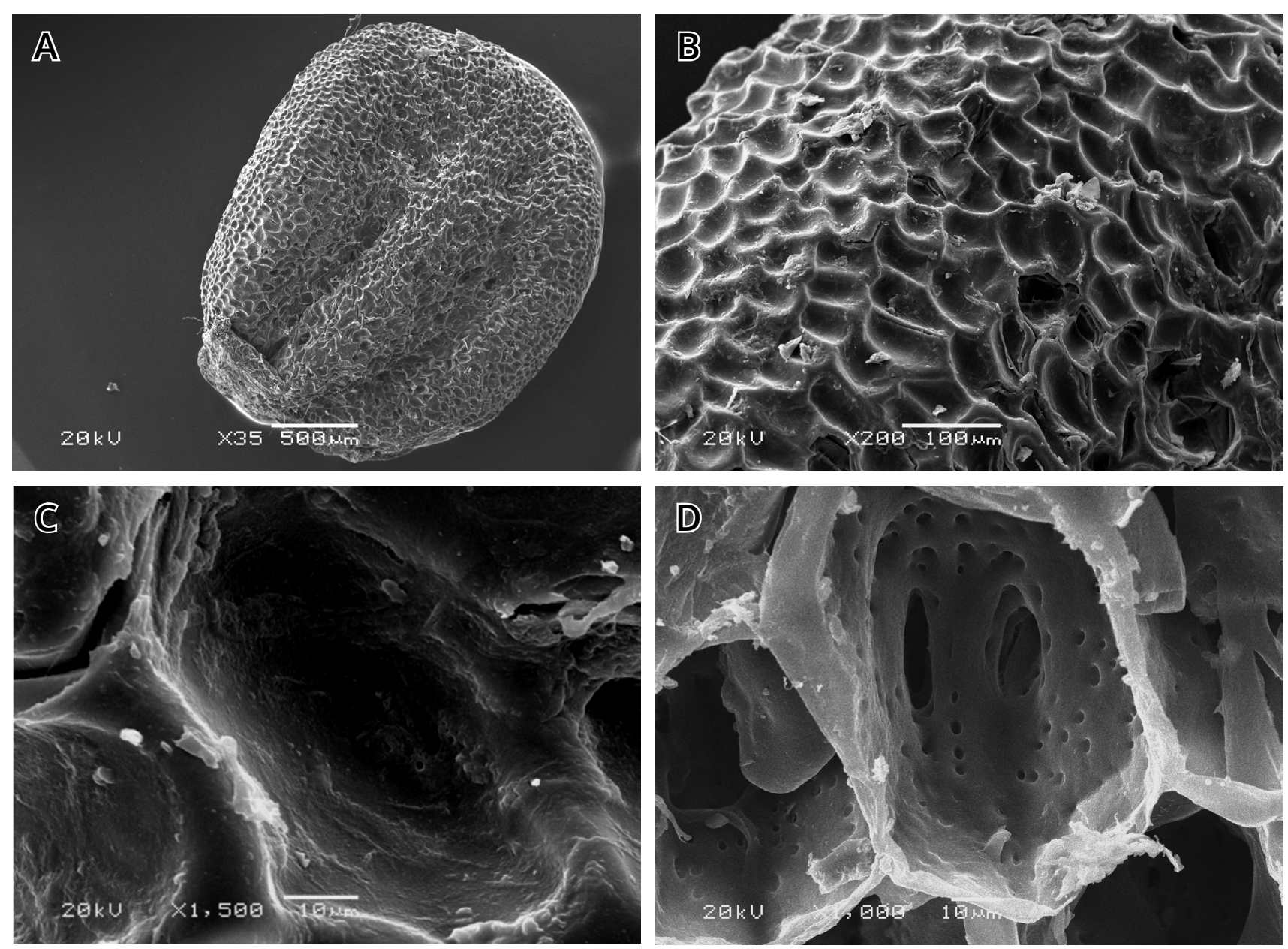

Figure 3. The seed of Lonicera tatarica: A - general view; B, C - surface; D - perforations on the internal periclinal and anticlinal cell walls of the testa.

celled glandular hairs with a spherical head (up to $100 \mu \mathrm{m}$ in length) and simple solitary hairs (up to $450 \mu \mathrm{m}$ in length). The surface of simple hairs is verrucose. The quantity of hairs increases at the apex of the fruit.

The seeds are light- or dark-brown, elliptical-rounded or asymmetrical, slightly curved, angular, 2.5-3.0 mm long and 2.0$2.7 \mathrm{~mm}$ wide, flat, slightly concave on one side, convex on the other, with a cavity on the periphery and a hardly noticeable crest in the center, narrow-rounded at the base. The hilum is small, submerged, located at the base of the seed.

The surface of the seed is shallowly pitted. The cells of the exotesta are polygonal, with concave periclinal and indistinct anticlinal walls. Outer periclinal walls are covered with a tortuous net visible at the magnification over $\times 500$.

Samples examined: 1 . Living plants from the collection of the O.V. Fomin Botanical Garden, 20.VII.2017. Leg., det.
N.M. Belemets, O.M. Tsarenko; 2. Sumy region, Sumy district, village Kijnytsa, Kijnitsky Arboretum, 26.V.1970, Leg., det. Litvinenko (KWHA); 3. Transcarpathian region, Rakhiv district, village Bogdan-Lusy (Tyschora), rocky places, 20.V.1953, Leg., det. Komendar (KW).

\section{Subgenus Periclymenum (L.) Rehder}

Section Eucaprifolium (Spach) Pojarkova Lonicera caprifolium L. (Fig. 5; Tables 1 \& 2)

Two fruits are free. Bracteoles are also free, small or absent. The fruits are bright-red, fleshy, spherical or elliptic, 5-8 mm long, 4- mm wide, with 1-5 seeds. The fruits are located on short pedicels as if they were coalescent to the leaves.

The seeds are light- or dark-brown, broadelliptical, sometimes rounded, often curved, 3-6 $\mathrm{mm}$ long and 2-3 $\mathrm{mm}$ wide, somewhat flat, slightly concave on one side, convex on the other, with a cavity on the periphery and a crest in the center, somewhat truncated at the base, with a small notch. The hilum is small, submerged, located at the base of the seed. 

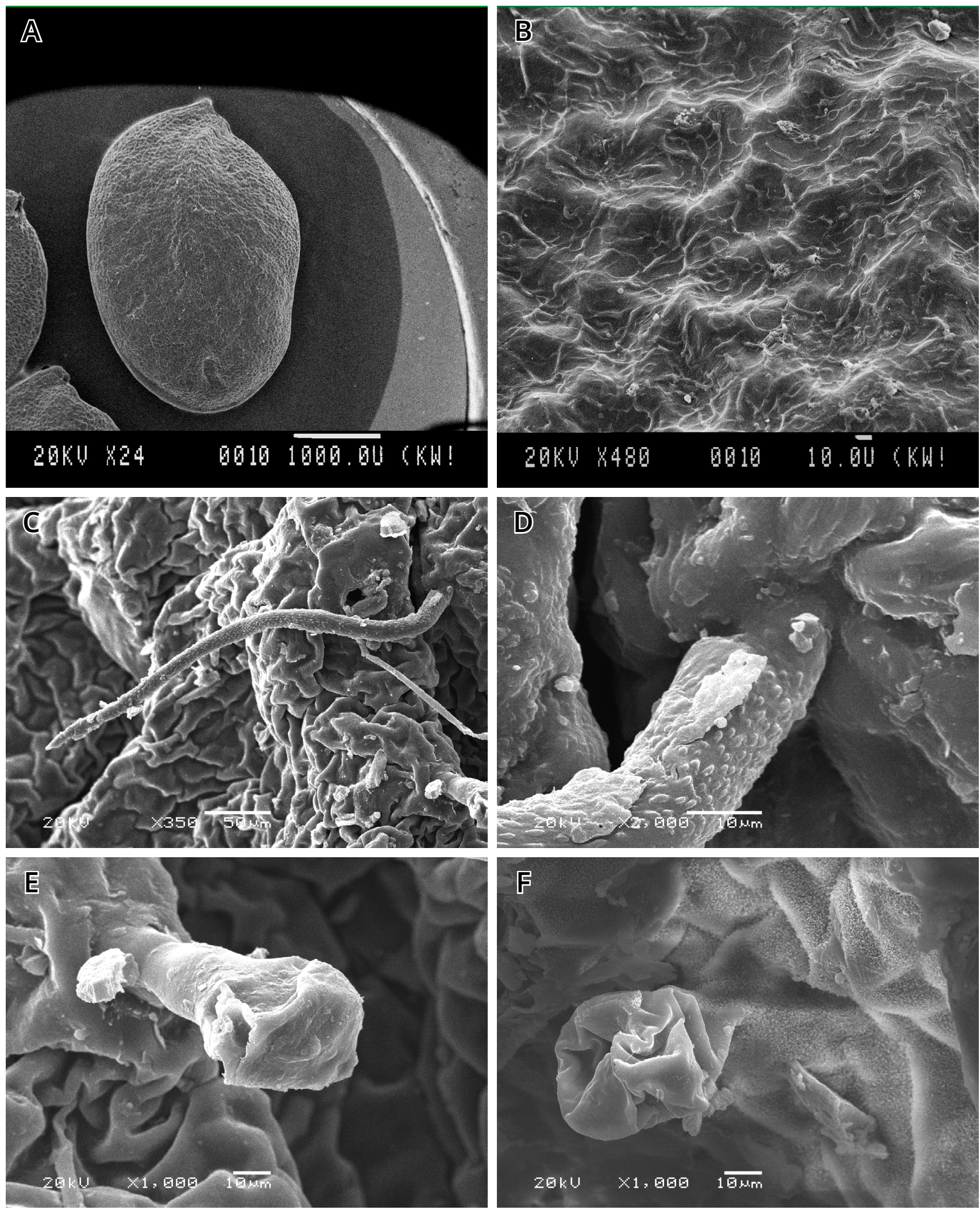

Figure 4. The seed (A, B) and the fruit (C-F) of Lonicera xylosteum: A - general view of the seed; $\mathbf{B}$ - surface of the seed; C, D - simple hair on the fruit; $E, F$ - glandular hair on the fruit.

The surface of the seeds is diversiform: in some areas of the seeds, it is pitted. In others - the cells of the exotesta are almost flat, with tortuous anticlinal walls, the walls of the cells are clearly visible. The outer periclinal walls are ribbed and wrinkled (seen at the magnification over $\times 1000$ ). 

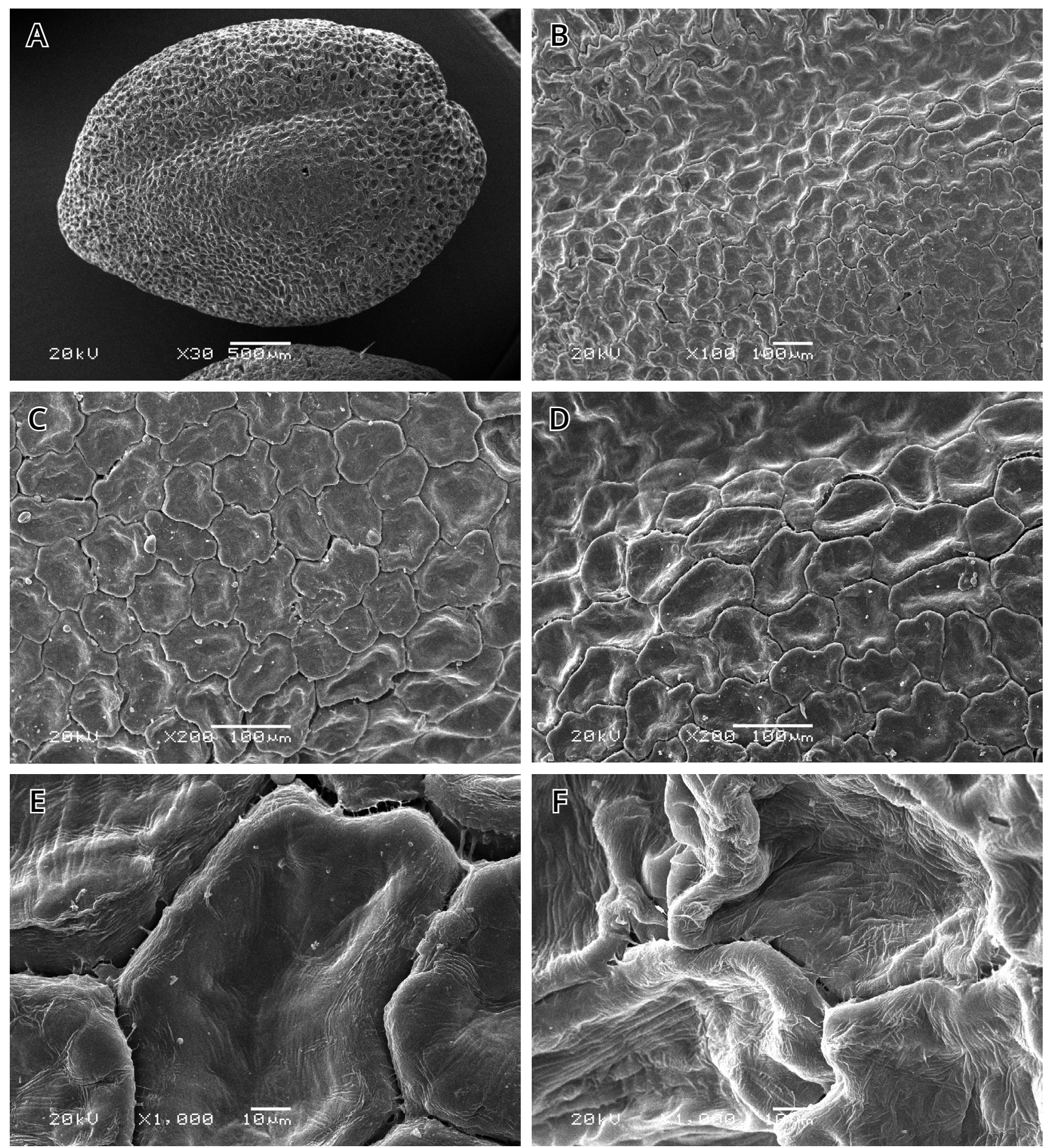

Figure 5. The seed of Lonicera caprifolium: A - general view; B-F - the surface of different seed sections.

Samples examined: 1. Yalta district, near Alushta, in the bushes of the park, 12.VIII.1959. Leg., det. Klokov (KW); 2. Living plants from the collection of the M.M. Gryshko National Botanical Garden of NAS of Ukraine, 26.IX.2017. Leg., det. O.M. Tsarenko; 3. Chernihiv, Agrobiostation, Arboretum, 19.V.2010, 097764. Leg., det. Pototskaya (KW).

\section{Lonicera periclymenum L. (Fig. 6; Tables 1 \& 2)}

Two free fruits, bracteoles are free too. The fruits are red, fleshy, spherical, up to $6 \mathrm{~mm}$ in diameter.
The seeds are light-brown, elliptical, ovoid, 2.0-3.5 mm long and 1.5-2.0 mm wide, flat, slightly concave on one side, convex on the other, with a cavity on the periphery and a crest in the center, narrow-rounded at the base, somewhat truncated. The hilum is small, submerged, located at the base of the seed.

The surface of the seeds is pitted in some areas of the seeds, and the cells of the exotesta are almost flat, with concave or more or less 

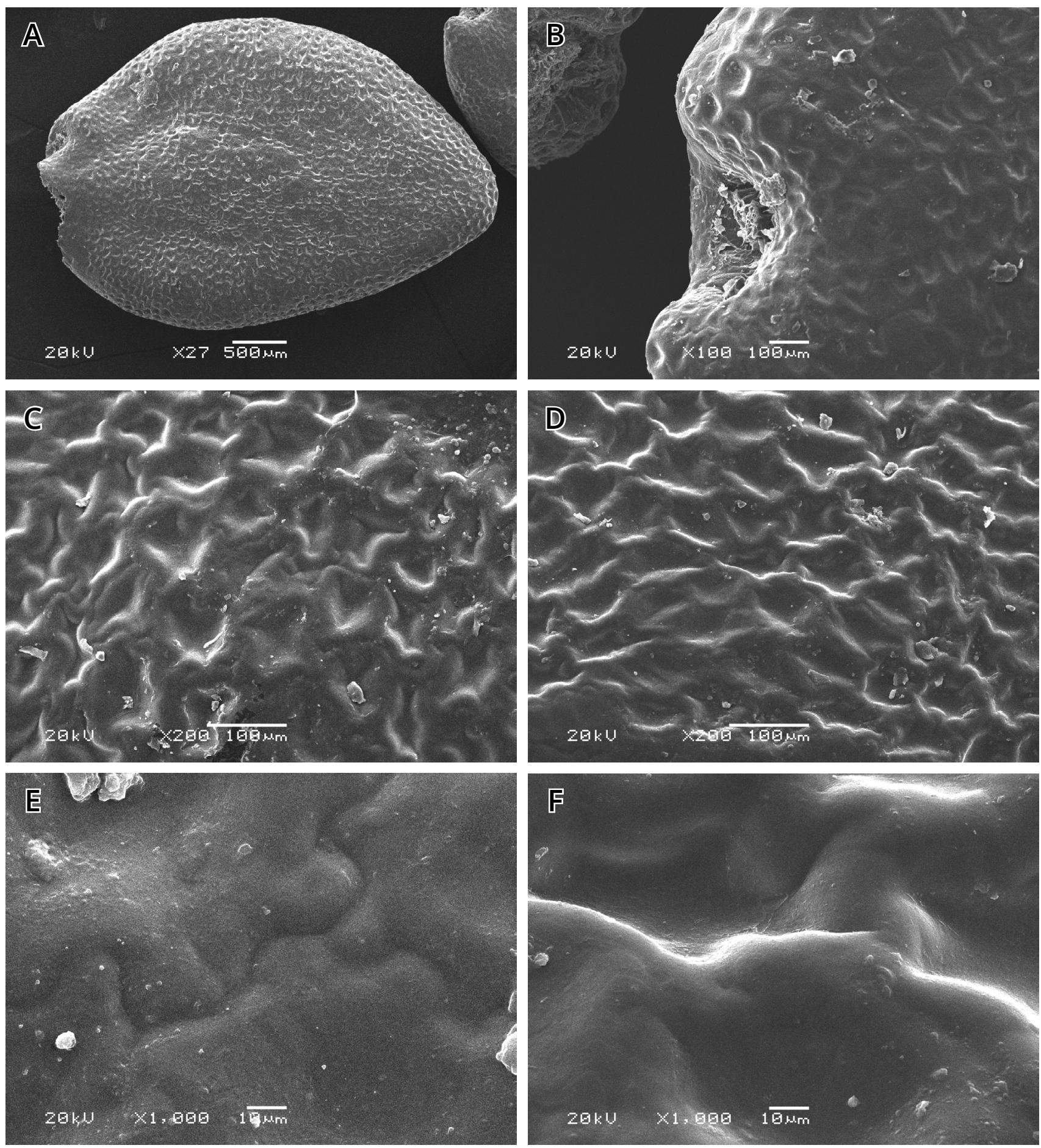

Figure 6. The seed of Lonicera periclymenum: A - general view; B - hilum; C-F - surface.

curved periclinal and tortuous anticline walls, the walls of the cell are distinctly visible. The outer periclinal walls are ribbed and wrinkled (seen at the magnification over $\times 1000$ ).

Samples examined: 1. Living plants from the collection of the M.M. Gryshko National Botanical Garden of NAS of Ukraine, 26.IX.2017. Leg., det. O.M. Tsarenko; 2. Crimea, Suuk-su, hotel park, 11.VI.1915. Leg. Tutkovsky, det. Mosyakin 17.I.1975 (KW).

\section{Lonicera etrusca Santi (Fig. 7; Tables 1 \& 2)}

Several fruits are free, some of which are much smaller or undeveloped. The bracteoles are free too. The fruits are red, fleshy, spherical, up to $8-10 \mathrm{~mm}$ in diameter.

The seeds are brown, broadly elliptical or ovoid, somewhat angular, 3.0-4.0 mm long and 2.7-3.5 mm wide, flattened-convex, slightly concave on one side, convex on the other, with 

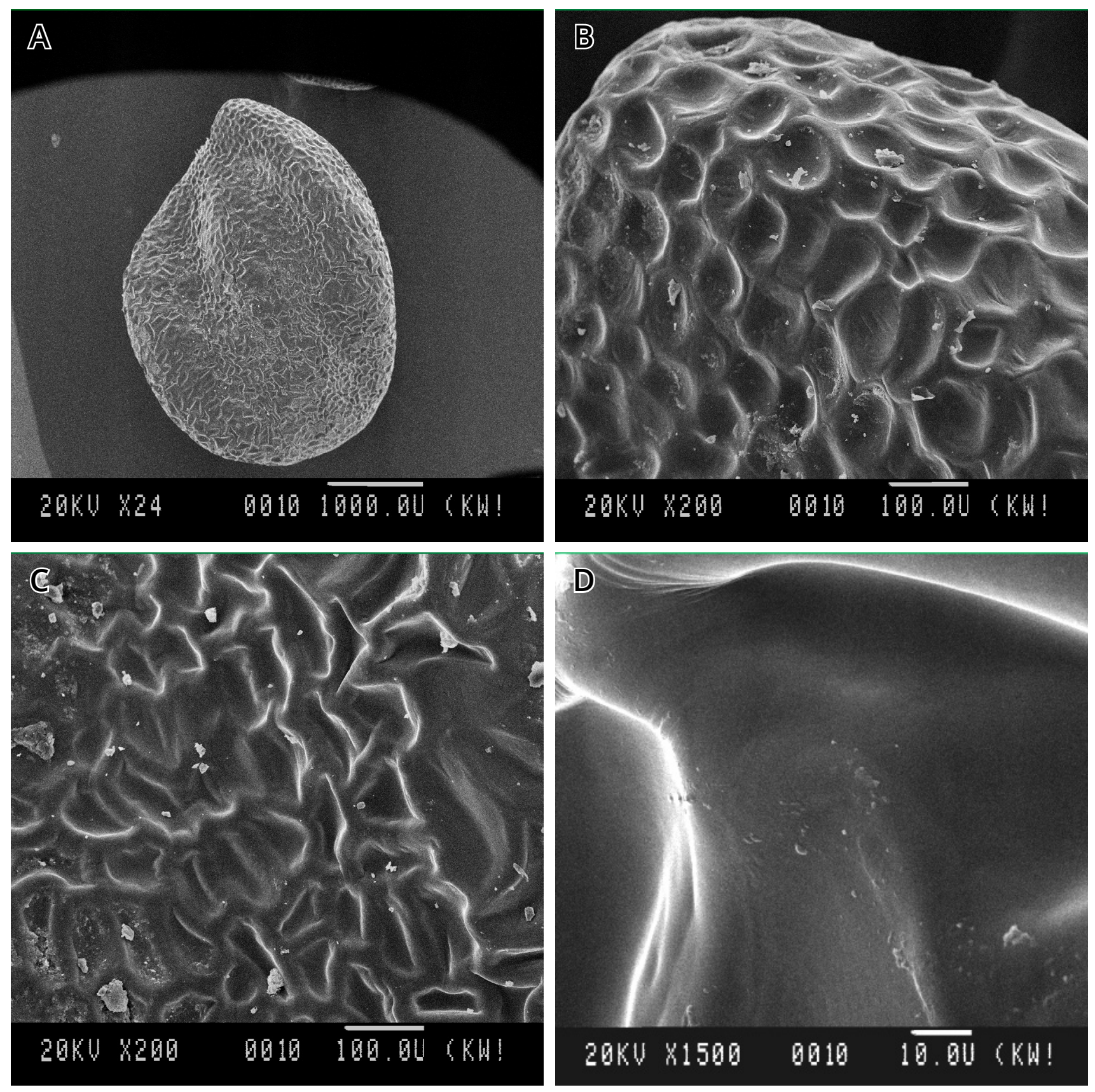

Figure 7. The seed of Lonicera etrusca: A - general view; B-D - surface at different magnification.

a cavity on the periphery and a crest in the center, asymmetrically truncated at the base. The hilum is small, submerged, located at the base of the seed.

The seed surface is pitted. The cells of exotesta are polygonal, with distinct borders, the cells have equally thickened anticlinal and concave periclinal walls. On the outer periclinal walls, ribs are visible at magnification over $\times 200$.

Samples examined: Living plants from the collection of the O.V. Fomin Botanical Garden, 20.VII.2017. Leg., det. N.M. Belemets, O.M. Tsarenko.

\section{Discussion}

According to our results, we did not find any characteristics that could be diagnostic at the level of subsections or higher. We have only found that there are some species-level differences in the microstructure of the seed surface. The surface of the seeds of all the species studied is almost identical. It is mostly pitted due to concave external periclinal walls of the exotesta. The surface of L. xylosteum seeds is shallowly pitted, as reported by Jacobs et al. (2009). However, the seed surface in L. nigra is tubercular-pitted. The seed surface 
Table 1. Morphological features of the fruit of Lonicera of the flora of Ukraine.

\begin{tabular}{|c|c|c|c|c|c|}
\hline Taxa & Construction & Color & Size & Shape & Pubescence \\
\hline \multicolumn{6}{|c|}{ Subgenus Chamaecerasus } \\
\hline \multicolumn{6}{|l|}{ Section Isika } \\
\hline \multicolumn{6}{|c|}{ Subsection Caeruleae } \\
\hline L. caerulea & $\begin{array}{l}\text { two free fruits; of } \\
\text { bracteoles of paired } \\
\text { flowers merged in a } \\
\text { tubular cupule }\end{array}$ & $\begin{array}{l}\text { dark blue } \\
\text { with bluish } \\
\text { cover }\end{array}$ & $\begin{array}{l}\text { 8-11 mm in } \\
\text { diameter }\end{array}$ & $\begin{array}{l}\text { spherical, } \\
\text { hemispherical, } \\
\text { elliptical }\end{array}$ & glabrouse \\
\hline \multicolumn{6}{|c|}{ Subsection Rhodanthae } \\
\hline L. nigra & $\begin{array}{l}\text { two fruits connate at } \\
\text { the base; bracteoles } \\
\text { incompletely connate into } \\
\text { a goblet-shaped cupule }\end{array}$ & $\begin{array}{l}\text { black with } \\
\text { bluish cover }\end{array}$ & $\begin{array}{l}6-10 \mathrm{~mm} \text { in } \\
\text { diameter }\end{array}$ & spherical & glabrouse \\
\hline \multicolumn{6}{|c|}{ Section Coeloxylosteum } \\
\hline \multicolumn{6}{|c|}{ Subsection Tataricae } \\
\hline L. tatarica & $\begin{array}{l}\text { two free fruits, bracteoles } \\
\text { are free }\end{array}$ & red, yellow & $\begin{array}{l}6-8 \mathrm{~mm} \text { in } \\
\text { diameter }\end{array}$ & $\begin{array}{l}\text { spherical, } \\
\text { sometimes } \\
\text { elliptical }\end{array}$ & glabrouse \\
\hline \multicolumn{6}{|c|}{ Subsection Ochranthae } \\
\hline L. xylosteum & $\begin{array}{l}\text { two connate only at the } \\
\text { base fruits; bracteoles are } \\
\text { free }\end{array}$ & $\begin{array}{l}\text { dark-red, } \\
\text { yellow }\end{array}$ & $\begin{array}{l}\text { 6-9 mm in } \\
\text { diameter }\end{array}$ & spherical & $\begin{array}{l}\text { sparsely pubescent } \\
\text { with glandular hairs } \\
\text { and solitary simple } \\
\text { hairs }\end{array}$ \\
\hline \multicolumn{6}{|c|}{ Subgenus Periclymenum } \\
\hline \multicolumn{6}{|c|}{ Section Eucaprifolium } \\
\hline L. caprifolium & $\begin{array}{l}\text { two free fruits; bracteoles } \\
\text { are free, small or absent }\end{array}$ & bright-red & $\begin{array}{l}5-8 \mathrm{~mm} \\
\text { long, } 4-5 \\
\text { mm wide }\end{array}$ & $\begin{array}{l}\text { spherical or } \\
\text { elliptic }\end{array}$ & glabrouse \\
\hline L. etrusca & $\begin{array}{l}\text { several free fruits, some of } \\
\text { which are much smaller or } \\
\text { undeveloped; bracteoles } \\
\text { are free }\end{array}$ & red & $\begin{array}{l}\text { 8-10 } \mathrm{mm} \text { in } \\
\text { diameter }\end{array}$ & spherical & glabrouse \\
\hline L. periclymenum & $\begin{array}{l}\text { free fruits; bracteoles are } \\
\text { free }\end{array}$ & red & $\begin{array}{l}6 \mathrm{~mm} \text { in } \\
\text { diameter }\end{array}$ & spherical & glabrouse \\
\hline
\end{tabular}

in L. caprifolium and L. periclymenum is pitted, but almost flat cells of the exotesta are also present.

Our research confirmed the feasibility of the fruit microcarpological features for more accurate identification of species-level taxa in the genus Lonicera. Only a few publications devoted to microcarpology of the genus Lonicera (Plysko, 2000; Jacobs et al., 2009; Lavrinenko, 2012). Several micromorphological characteristics of Lonicera species have been applied to confirm the molecular phylogeny of the genus (Jacobs et al., 2009). These features also can be successfully applied for resolving controversial questions of taxonomy, what has been shown for Dipsacales (Tsymbalyuk et al., 2018; Tsarenko et al., 2019) and some rare Caryophyllales Juss. ex Bercht. et J. Presl (Amini et al., 2011; Martynyuk et al., 2015a, 2015b, 2016, 2018; Shykhaleyeva et al., 2018).

The fruits of studied species, excepting L. xylosteum, are reported as glabrous (Poyarkova, 1958; Zaytsev, 1962; Browicz, 1976; Artiushenko \& Fedorov, 1986; Jacobs et al., 2009). Our observation confirmed the absence of trichomes on the fruits of L. caerulea, L. nigra, L. tatarica, L. caprifolium, L. periclymenum, and L. etrusca. Only fruits of L. xylosteum have been sparsely pubescent by glandular two-celled headed and simple (with 
Table 2. Macro- and micromorphological features of the seed of Lonicera of the flora of Ukraine.

\begin{tabular}{|c|c|c|c|c|}
\hline Taxa & Color & Size & Shape & Surface \\
\hline \multicolumn{5}{|c|}{ Subgenus Chamaecerasus } \\
\hline \multicolumn{5}{|l|}{ Section Isika } \\
\hline \multicolumn{5}{|c|}{ Subsection Caeruleae } \\
\hline L. caerulea & $\begin{array}{l}\text { light- or } \\
\text { dark-brown }\end{array}$ & $\begin{array}{l}1.5-2.3 \mathrm{~mm} \text { long and } \\
1.4-2.1 \mathrm{~mm} \text { wide }\end{array}$ & broadly elliptical or rounded & mostly pitted \\
\hline \multicolumn{5}{|c|}{ Subsection Rhodanthae } \\
\hline L. nigra & $\begin{array}{l}\text { light- or } \\
\text { dark-brown }\end{array}$ & $\begin{array}{l}2.2-2.5 \mathrm{~mm} \text { long and } \\
1.8-2.4 \mathrm{~mm} \text { wide }\end{array}$ & elliptical & tuberculate-pitted \\
\hline \multicolumn{5}{|c|}{ Section Coeloxylosteum } \\
\hline \multicolumn{5}{|c|}{ Subsection Tataricae } \\
\hline L. tatarica & $\begin{array}{l}\text { light- or } \\
\text { dark-brown }\end{array}$ & $\begin{array}{l}3.0-3.5 \mathrm{~mm} \text { long and } \\
1.5-2.7 \mathrm{~mm} \text { wide }\end{array}$ & elliptical & pitted \\
\hline \multicolumn{5}{|c|}{ Subsection Ochranthae } \\
\hline L. xylosteum & $\begin{array}{l}\text { light- or } \\
\text { dark-brown }\end{array}$ & $\begin{array}{l}2.5-3.0 \mathrm{~mm} \text { long and } \\
2.0-2.7 \mathrm{~mm} \text { wide }\end{array}$ & $\begin{array}{l}\text { elliptical-rounded, asymmetrical, } \\
\text { slightly curved, angular }\end{array}$ & pitted \\
\hline \multicolumn{5}{|c|}{ Subgenus Periclymenum } \\
\hline \multicolumn{5}{|c|}{ Section Eucaprifolium } \\
\hline L. caprifolium & $\begin{array}{l}\text { light- or } \\
\text { dark-brown }\end{array}$ & $\begin{array}{l}3.0-6.0 \mathrm{~mm} \text { long and } \\
2.0-3.0 \mathrm{~mm} \text { wide }\end{array}$ & $\begin{array}{l}\text { broad-elliptical, sometimes } \\
\text { rounded, often curved }\end{array}$ & $\begin{array}{l}\text { pitted and the cells of } \\
\text { the exotesta almost flat }\end{array}$ \\
\hline L. etrusca & brown & $\begin{array}{l}3.0-4.0 \mathrm{~mm} \text { long and } \\
2,7-3,5 \mathrm{~mm} \text { wide }\end{array}$ & $\begin{array}{l}\text { broadly elliptical, ovoid, } \\
\text { somewhat angular }\end{array}$ & pitted \\
\hline L. periclymenum & light-brown & $\begin{array}{l}2.0-3.5 \mathrm{~mm} \text { long and } \\
1.5-2.0 \mathrm{~mm} \text { wide }\end{array}$ & elliptical, ovoid & $\begin{array}{l}\text { pitted and the cells of } \\
\text { the exotesta almost flat }\end{array}$ \\
\hline
\end{tabular}

a finely warty surface) hairs. Other observed morphological features of the studies species also corresponded to descriptions reported before (Rehder, 1909; Poyarkova, 1958; Barbarych, 1961; Zaytsev, 1962; Browicz, 1976; Jacobs et al., 2009; Lavrinenko, 2016).

\section{Conclusions}

Based on the results of the analysis of literary sources and our own data of macro- and micromorphological studies of the fruits and seeds of representatives of the genus Lonicera, their detailed characteristics were prepared. It should facilitate the more precise identification of the species in the fruiting state. A carpological feature that is specific to representatives of the subgenus Periclymenum is the presence of exclusively free fruits, unlike representatives of the subgenus Chamaecerasus with both free and connate at the base fruits.
At the species level, we suggest using the following features of fruits and seeds: differences in fruits coloration of representatives of the genus; the presence of pseudocarp in the L. caerulea; the difference in shape (i.e., for L. caerulea and L. tatarica with the spherical, elliptical shape of the fruits was also noted); the presence of glandular and simple hairs on fruits of L. xylosteum; the difference in the shape of the seeds (elliptic or ovoid in L. etrusca, L. nigra, and L. tatarica, and broadly elliptic or almost rounded in L. caerulea, L. periclymenum, and L. xylosteum).

There are no characteristics of the microstructure of the surface of the seed that can be diagnostic at the level of subsections or higher. The seeds have only some differences at the species level. In most of the studied species, the seed surface is pitted - seeds of L. nigra are tubercular-pitted and seeds of L. xylosteum with shallow-pitted surfaces, while seeds of L. caprifolium and L. periclymenum have almost flat exotesta cells. 


\section{References}

Amini, E., Shahin, Z., \& Assadi, M. (2011). Seed micromorphology and its systematic significance in Gypsophila (Caryophyllaceae) and allied genera. Nordic Journal of Botany, 29(6), 660-669. https://doi.org/10.1016/j.flora.2017.07.004

APG. (2016). An update of the Angiosperm phylogeny Group classification for the orders and families of flowering plants: APG IV. Botanical Journal of the Linnean Society, 181, 1-20. https:// doi.org/10.1111/boj.12385

Artiushenko, Z. T., \& Fedorov, A. A. (1986). Atlas on the descriptive morphology of higher plants. Fruit. Leningrad: Nauka. (In Russian)

Barbarych, A. I. (1961). Honeysuckle family Caprifoliaceae Juss. In M.I. Kotov (Ed.), Flora of UkrSSR. Vol. 10 (pp. 249-285). Kyiv: Publishing house of the Academy of Sciences of UkrSSR. (In Ukrainian)

Bell, C. D., \& Donoghue, M. J. (2005). Dating the Dipsacales: Comparing models, genes, and evolutionary implications. American Journal of Botany, 92, 284-296. https://doi.org/10.3732/ ajb.92.2.284

Bell, C. D., Edwards, E. J., Kim, S.-T., \& Donoghue, M. J. (2001). Dipsacales phylogeny based on chloroplast DNA sequences. Harvard Papers in Botany, 6(2), 481-499.

Browicz, K. (1976). Lonicera L. In T. G. Tutin, V. H. Heywood, N. A. Burges, D. M. Moore, D. H. Valentine, S. M. Walters, D. A. Webb (Eds.), Flora Europaea. Volume 4. Plantaginaceae to Compositae (and Rubiaceae) (pp. 46-48). Cambridge: Cambridge University Press.

Donoghue, M. J., Bell, C. D., \& Winkworth, R. C. (2003). The evolution of reproductive characters in Dipsacales. International Journal of Plant Sciences, 164, 453-464. https://doi. org/10.1086/376874

Glukhov, A. Z., Kostyrko, D. R., \& Osavlyuk, S. N. (2002). Species of the genus Honeysuckle (Lonicera L.) in South-Eastern Ukraine. Introduction, biomorphology, use. Donetsk: OOO "Lebed". (In Russian)

Göktürk, R. S., \& Sümbül, H. A. (2014). The taxonomic revision of the genus Cephalaria (Caprifoliaceae) in Turkey. Turkish Journal of Botany, 38, 927-968. https://doi.org/10.3906/bot-1310-6

Jacobs, B., Donoghue, M. J., Bouman, F., Huysmans, S., \& Smets, E. (2008). Evolution and phylogenetic importance of endocarp and seed characters in Viburnum (Adoxaceae). International Journal of Plant Sciences, 169, 409-431. https://doi. org/10.1086/526468
Jacobs, B., Lens, F., \& Smets, E. (2009). Evolution of fruit and seed characters in the Diervilla and Lonicera clades (Caprifoliaceae, Dipsacales). Annals of Botany, 104, 253-276. https://doi. org/10.1093\%2Faob\%2Fmcp131

Lavrinenko, V. M. (2012, June 5-8). Morphometric indicators of seeds of some species of the genus Lonicera L. In Proceedings of the International Scientific Conference "Dendrology, Floriculture and Gardening", dedicated to the 200th anniversary of the Nikita Botanical Garden (p. 75). Yalta: Publishing house of the National Science Center. (In Ukrainian)

Lavrinenko, V. M. (2016). Species of the genus Lonicera L. in nature and culture in Ukraine (biological features, distribution, use) [PhD thesis]. Kyiv. (In Ukrainian)

Malinkina, Y. V. (2001). Patterns of morphological and anatomical structure formation, oil content of fruits and the content of biologically active substances in them in representatives of the genus Lonicera L. (PhD thesis). Moscow. (In Russian)

Martynyuk, V. O., Karpenko, N. I., \& Tsarenko, O. M. (2015a). Micromorphological features of pollen grains, seeds and leaf surfaces of Atocion hypanicum (Klok.) Tzvel. and A. compactum (Fisch.) Tzvel. Modern Phytomorphology, 7, 95-101. (In Ukrainian). https://doi.org/10.5281/zenodo.160373

Martynyuk, V. O., Karpenko, N. I., \& Tsarenko, O. M. (2015b). Some micromorphological features of Atocion lithuanicum (Zapał.) Tzvel. and A. armeria (L.) Raf. of Ukrainian flora. Biological Bulletin of Bogdan Khmelnitskiy Melitopol State Pedagogical University, 5(1), 8-23.

Martynyuk, V. O., Karpenko, N. I., \& Tsarenko, O. M. (2018). Comparative analysis of micromorphological characters in two closely related species, Silene syreistschikowii and S. supina (Caryophyllaceae). Biological Systems, 10(1), 8493. (In Ukrainian)

Martynyuk, V., Karpenko, N., \& Tsarenko, O. (2016). Micromorphological features of the narrowlocus endemic Silene sytnikii (Caryophyllaceae) in comparison with similar species. Bulletin of the Taras Shevchenko National University of Kyiv. Biology Series, 1(73), 25-31. (In Ukrainian)

Mosyakin, S. L., \& Fedoronchuk, M. M. (1999). Vascular plants of Ukraine. A nomenclatural checklist. Kyiv.

Plysko, M. A. (2000). Family Caprifoliaceae. In A. L. Takhtajan (Ed.), Comparative anatomy of seeds. Vol. 6. Dicotyledonous. Rosidae II (pp. 367383). Saint-Petersburg: Nauka. (In Russian)

Poyarkova, A. I. (1958). Honeysuckle-Caprifoliaceae Vent. In B. K. Shyshkin (Ed.), Flora of USSR. Vol. 23 (pp. 419-584). Moscow - Leningrad: Publishing house of the Academy of Sciences of USSR. (In Russian) 
Rehder, A. (1909). Note on the morphology of the fruit of Lonicera caerulea. Rhodora, 11(131), 209-211. Retrieved from https://www.jstor.org/ stable/23296043

Reveal, J. L. (2012). An outline of a classification scheme for extant flowering plants. Phytoneuron, 37(1), 1-221.

Shykhaleyeva, G. M., Tsarenko, O. M., Tsymbalyuk Z. M., Ennan, A. A., \& Kiryushkina, A. M. (2018). Morphological features of generative organs of Salicornia perennans (S. prostrata) (Chenopodiaceae) of the Kuialnytsky Estuary coast. Ukrainian Botanical Journal, 75(5), 470479. https://doi.org/10.15407/ukrbotj75.05.470

Takhtajan, A. (2009). Flowering Plants. $2^{\text {nd }} E d .$. New York: Springer-Verlag. https://doi. org/10.1007/978-1-4020-9609-9

Theis, N., Donoghue, M. J., \& Jianhua, L. (2008). Phylogenetics of the Caprifolieae and Lonicera (Dipsacales) based on nuclear and chloroplast DNA sequences. Systematic Botany, 33, 776-783. https://doi.org/10.1600/036364408786500163

Tsarenko, O. M., Bulakh, O. V., \& Dremliuga, N. G. (2019). Carpological features of species of the genus Cephalaria (Dipsacaceae) of the flora of Ukraine. Chornomorski Botanical Journal, 15(3), 229-242. https:// doi.org/10.32999/ksu1990-553X/2019-15-3-2

Tsymbalyuk, Z. M., Tsarenko, O. M., Dremliuga, N. G., Bulakh, O. V., \& Nitsenko, L. M. (2018). Morphological peculiarities of generative organs of Linnaea borealis. Chornomorski Botanical Journal, 14(1), 32-42. https://doi. org/10.14255/2308-9628/18.141/3
Zaitseva, E. S. (1998). Comparative anatomy of the fruits of the Dipsacaceae family in connection with questions of its phylogeny. In Abstracts of the $2^{\text {nd }}(10)$ Congress of the Russian Botanical Society "Problems of botany at the turn of the XXXXI centuries". Vol. 2 (p. 36). Saint-Petersburg. (In Russian)

Zaitseva, E. S. (1999). Comparative carpology of representatives of the Dipsacales order in connection with questions of their systematic and phylogeny. In Materials of the X Moscow Conference on Plant Phylogeny (pp. 80-82). Moscow. (In Russian)

Zaitseva, E. S. (2006). Comparative carpology of order Dipsacales in connection with questions of its systematic (PhD thesis). Moscow. (In Russian)

Zaytsev, G. N. (1962). Genus Lonicera - Honeysuckle. In S. Y. Sokolov (Ed.), Trees and shrubs of the USSR. Vol. 6 (pp. 211-299). Moscow - Leningrad: Publishing house of the Academy of Sciences of USSR. (In Russian)

Ziman, S. M., Hrodzynskyi, D. M., \& Bulakh, O. V. (2011). Latin-English-RussianUkrainian dictionary of terms on morphology and systematics of vascular plants. Kyiv: Naukova Dumka. (In Ukrainian)

Ziman, S. M., Mosyakin, S. L., Bulakh, O. V., Tsarenko, O. M., \& Felbaba-Klushina, L. M. (2004). Illustrated handbook of the flower plant morphology. Uzhhorod: Medium. (In Ukrainian)

\section{Карпологічні особливості Lonicera L. (Caprifoliaceae Juss.) флори України}

О.М. Царенко ${ }^{1 *}$, О.В. Булах ${ }^{1}$, О.В. Колесніченко ${ }^{2}$, С.М. Грисюк ${ }^{2}$

\footnotetext{
1 Інститут ботаніки імені М.Г. Холодного НАН України, вул. Терещенківська, 2, м. Київ, 01004, Україна;

* tsarenko_olga@ukr.net; anemone@ukr.net

${ }^{2}$ Національний університет біоресурсів і природокористування України, вул. Героїв оборони, 15, м. Київ, 03041, Україна
}

Мета - провести макро- та мікроморфологічні дослідження плодів та насінин природних й інтродукованих представників роду Lonicera флори України, уточнити їхні особливості, надати доповнену характеристику та оцінити можливість використання карпологічних ознак для діагностики таксонів цього роду.

Матеріал і методи. Для досліджень було залучено матеріал з Національного гербарію Інституту ботаніки імені М.Г. Холодного НАН України (KW) і гербарію Національного ботанічного саду імені М.М. Гришка НАН України (KWHA), а також відібрано зразки з живих рослин у колекціях 
Національного ботанічного саду імені М.М. Гришка та Ботанічного саду імені О.В. Фоміна. Цитування опрацьованих зразків представлено відповідно до оригінального тексту етикеток. Загалом було досліджено морфологічні ознаки плодів та насінин семи видів роду (чотири з яких $\epsilon$ інтродуцентами, а решта - види природної флори), що вказані у "Vascular plants of Ukraine. A nomenclatural checklist". Для досліджень використовували світловий (МБС-9) та сканувальний електронний (USM-6060 LA) мікроскопи. Зразки напилювали шаром золота за стандартною методикою. Дослідження проводили при збільшенні від ×30 до ×3000. Описи плодів і насінин здійснювали з використанням загальноприйнятої ботанічної термінології. Виміри розмірів плодів та насінин виконували 3 використанням програми Axio Vision Rel. 4.8.

Результати. Представники досліджених видів мають вільні або зрослі при основі плоди, оточені обгорткою з переважно вільних приквітничків. Псевдокарпій L. caerulea сформований бракеолями парних квіток, які зростаються у трубчасту обгортку, що повністю і щільно обгортає вільні парні плоди. Для L. nigra відмічено нерівномірне зростання приквітничків між собою, які вільно оточують парні плоди, що зрослися лише при основі. Плоди досліджених видів за забарвленням чорні, темно-сині, червоні та жовті. Для підроду Periclymenum (L. caprifolium, L. etrusca, L. periclymenum) характерні вільні та кулясті за формою плоди. У видів підроду Chamaecerasus плоди переважно кулясті, але у деяких представників разом з кулястими трапляються також напівкулясті, еліптичні та видовжені (L. caerulea, L. tatarica) плоди, які можуть бути як вільними (L. caerulea, L. tatarica), так й зрослими при основі (L. nigra, L. xylosteum). Для всіх досліджених видів, за виключенням L. xylosteum, характерні голі плоди. Поверхня плодів L. xylosteum опушена залозистими та простими волосками. Насінини досліджених видів за формою еліптичні, яйцеподібні, майже округлі, сплюснуті, з одного боку ввігнуті та з іншого опуклі, з заглибленням по периферії та гребенем по центру, переважно зі звужено-заокругленою основною. Досліджені представники секції Eucaprifolium та один вид 3 секції Coeloxylosteum мають усічені при основі насінини. Поверхня насінин всіх досліджених видів майже однакова. Вона здебільшого ямкувата, але у L. xylosteum - вона неглибоко-ямкувата, у L. nigra - горбкувато-ямкувата, а у деяких видів відмічена не лише ямкувата структура поверхні, а також присутність майже пласких клітин екзотести.

Висновки. За результатами опрацювання літературних джерел та на підставі аналізу власних даних макро- та мікроморфологічних досліджень плодів та насінин представників роду Lonicera в межах флори України складено їхні детальні характеристики, що сприятиме точнішому визначенню цих видів у стані плодоношення. Відмічено, що у представників підроду Periclymenum плоди виключно вільні, на відміну від підроду Chamaecerasus, у представників якого плоди можуть бути як вільними так і зрослими при основі. Особливості забарвлення плодів, форми плодів та насінин, а також особливості опушення плодів запропоновано використовувати для визначення видів L. caerulea, L. caprifolium, L. etrusca, L. nigra, L. periclymenum, L. tatarica та L. хуlosteum. У результаті досліджень не виявлено ознак мікроструктури поверхні насінин, за якими можна діагностувати представників на рівні підсекцій, секцій та підродів, проте встановлено, що вони можуть частково використовуватися для розмежування таксонів на видовому рівні.

Ключові слова: Lonicera, плід, насінина, макроморфологічні особливості, мікроморфологічні особливості, мікроструктура поверхні насінини, флора України 